\title{
Challenge FOR CAUSE
}

\author{
The Right Honourable Lord Justice Phillips*
}

In this article his Lordship examines the operation of juries in England and considers how the English experience may assist the New Zealand Law Commission in the reform process. His Lordship addresses three aspects: first, the implications of jury operation and selection processes; second, the role of the law of evidence in determining the guilt or innocence of an accused; third, whether juries are the appropriate finder of fact in trials concerning serious fraud. The material in this article was originally delivered as a public lecture on 27 March 1996 in the Faculty of Law.

\section{INTRODUCTION}

"The lamp that shows that freedom lives." So Mr Justice Devlin described trial by jury in the last of his celebrated Hamlyn Lectures delivered 40 years ago. ${ }^{1}$ In the United Kingdom no serious challenge has since been made to the belief that the right to trial by jury is one of the essential foundations of our constitution. In Northern Ireland that right has been regretfully suspended in some emergency situations, but no politician has had the temerity to question the desirability of jury trial in a free society. I believe that the same is true in New Zealand. In both jurisdictions, however, concern has been expressed at some aspects of the procedures of jury trial.

The principles and practices relating to trial by jury are not writ in stone. If demonstration of this is needed I would remind you that the justification for the jury was, originally, that the jurors would have personal knowledge of the subject matter of the enquiry. Today any such knowledge will result in disqualification of the juror in question.

In this lecture I propose to comment on certain aspects of jury trial in my jurisdiction that have caused me concern. But I thought it might be helpful first to look at some of the specific aspects of jury trial that are receiving attention from your Law Commission in case our experience has anything to offer.

* The Right Honourable Lord Justice Phillips was the Judge in Residence at the Faculty of Law during March and April 1996.

1 Sir Patrick Devlin Trial by Jury (Steven \& Sons Ltd, London, 1956) 164. 


\section{QUALIFICATION TO SERVE AS A JUROR}

The rules governing those who are qualified to serve as jurors have changed fundamentally over the last century. It is hard to believe that within living memory women were not qualified to sit on a jury. "Twelve good men and true" meant what it said. Prior to 1974 jurors were restricted to householders who paid rates. Under the Juries Act 1974, and subject to specific exceptions, the qualification to serve on a jury was extended to anyone on the electoral register. Thus jurors can be as young as 18 . The statutory upper age limit is 70. This contrasts with New Zealand where the lower age limit is 20 and there is no upper limit.

England, like New Zealand, has a list of those who are disqualified or ineligible. We are somewhat stricter than you about disqualifying those with criminal records. No one sentenced to imprisonment or community service within the last ten years can serve. In New Zealand the sentence must be at least three months to disqualify, and if the sentence is less than three years the disqualification only lasts for five.

As in New Zealand, those called up to do service who demonstrate that there is good reason why they should not serve are excused. The English Act does not define "good reason" - New Zealand's sets out wide categories of grounds for exclusion, which include "the nature of the person's occupation or business" and "personal circumstances that would result in serious inconvenience".

The reality is - at least in England - that if you really do not want to serve on a jury and are not too scrupulous about the truth - you are likely to be able to escape jury service. I believe that in England those who are excused or simply do not show up in answer to a jury summons exceed $50 \%$. In a recent lengthy serious fraud trial I had to require 1,000 jurors to be summoned which resulted in a panel of no more than two hundred from which the jury was selected.

In England concern has recently been expressed about the composition of the jury. There is a perception that the more able and intelligent members of our society routinely evade jury service - with or without good reason - so that juries are unrepresentative and often lack any member capable of the logical analysis that is needed to instil some order into the deliberations. There have been calls for a minimum educational qualification for jury service.

I know of no statistical basis for the theory that juries are not fairly representative of society as a whole, but it seems to me desirable that there should be some analysis of composition of juries to see whether these perceptions are well founded. I do not myself believe in pressing those who are really unwilling to serve on juries. A disgruntled juror seems to me to represent a potential threat to sound deliberation. If the stage is reached 
when the majority of the population are not prepared to observe the duty of the citizen to do his or her spell of jury service, then I believe that the time has come to do away with the jury.

I now come to a question that has vexed both England and New Zealand. Should composition of a jury be controlled to achieve a specific racial or gender mix, either with the aim of ensuring a balanced jury or of tailoring the composition of the jury to one that is appropriate having regard to the particular characteristics of the accused. In England we have finally set our face firmly against such a course. There have been cases where the judge accepted that it was proper to take steps to influence the ethnic composition of the jury - for example $R v$ Thomas $^{2}$ and $R v$ Bansal, $^{3}$ where Woolf J directed that the jury panel should be selected from a particular area known to contain a high proportion of members of the Asian community.

In $R v$ Ford, ${ }^{4}$ Lord Lane CJ held that such a course was inappropriate. In that case a black defendant, convicted by an all white jury, appealed on the ground that the judge had wrongfully refused his application to ensure that a multi-racial jury was selected. In giving judgment Lord Lane said:

... however well intentioned the judge's motive might be, the judge has no power to influence the composition of the jury, and that it is wrong for him to attempt to do so. If it should ever become desirable that the principle of random selection should be altered, that will have to be done by way of statute and cannot be done by any judicial decision.

We wish to make two final further points. It appears to have been suggested in some of the cases that there is a "principle" that a jury should be racially balanced .... No authority is cited by those who have argued for the existence of the principle. In our judgment such a principle cannot be correct, for it would depend on an underlying premise that jurors of a particular racial origin or holding particular religious beliefs are incapable of giving an impartial verdict in accordance with the evidence.

Secondly, the principles we have already seı out apply not only where it is argued that a jury of a particular composition ought to be empanelled because of the nature of the particular case or particular defendants, but also where complaint is made that the panel was not truly "random", for instance that the population of a particular area contained $20 \%$ of persons of West Indian origin but that only a much lower percentage of such persons was to be found on the panel. For the judge to entertain any such application would equally involve his seeking to investigate the composition of the panel in a manner which, for reasons already indicated, lies outside his jurisdiction, and lies within the jurisdiction of the Lord Chancellor.

2 (1989) 88 Cr App R 370.

3 [1985] Crim LR 151.

4 [1989] QB 868. 
I would not presume to judge whether these observations are appropriate for New Zealand, but perhaps they merit consideration.

\section{A Peremptory Challenge}

In his Hamlyn lectures, Sir Patrick Devlin made reference to the practice in America of selecting a jury on the voir dire - that is by individual oral examination of potential jurors. He remarked that: "The voir dire can occupy quite an appreciable time"5 - illustrating this statement by reference to the fact that in the first trial of Alger Hiss the voir dire lasted just over two hours. Today, as I understand it, jury selection in the United States can extend for days. The exercise is seen by the defence as an opportunity to tailor the composition of the jury to one that is likely to be sympathetic to the defendant. At its most sophisticated this exercise can involve the use of consultant psychiatrists to build up a profile of the ideal juror, which is then used as a blueprint during the voir dire.

Devlin remarked that this procedure would not be acceptable in England: 6

By the end of it the advocate has found out a good deal about the jurors and it is inevitable that his conduct of the case and style of oratory will be influenced by the desire to appeal to them as individuals. The English tradition is that advocacy should be quite impersonal: counsel should ... address the jury as an impersonal body of twelve and the less they know about them as men and women the better.

This aspect of the English tradition came under threat when it became apparent that in some trials defence counsel were taking advantage of the right of peremptory challenge to try to ensure that juries had a composition that rightly or wrongly (probably wrongly) was expected to be sympathetic to the defendant. The reaction of the legislature to such tactics was a steady reduction of the right of peremptory challenge from the 35 allowed at common law to seven in 1948 and thence to 3 by the Criminal Law Act 1977. But even this did not defeat the practice in multi-hander cases where defence counsel combined to use their rights to challenge to a common end, so under the Criminal Justice Act 1988 the right of peremptory challenge was abolished.

You still have the right of peremptory challenge. In England I believe that its abolition has been salutary - over all. Jury selection is now usually a quick and straightforward process. The peremptory challenge when used to attempt to tailor a jury having regard to the perception of defence counsel as to the type of juror who would or would not be favourable to the defence case or the defendant was inappropriate, unattractive and, I suspect, usually misguided.

5 Above n 1, 33.

6 Above n 1, 33-34. 
There is, however, one snag about the withdrawal of the right of peremptory challenge. Sometimes one has only to look at a juror, or to hear the manner in which the oath is read, to appreciate that the juror is totally unsuitable to be entrusted with the responsibility for determining a verdict or any responsibility. In the past defence counsel could be expected to challenge such a juror. In a recent case, it was only the combined weight of defence counsel that persuaded prosecuting counsel that it was appropriate for the prosecution to exercise their right to stand by such a juror. It is certainly easier and less embarrassing for the defence to exclude the obviously inadequate juror by peremptory challenge.

\section{B Jury Screening}

In England the media are expected to refrain from publications which risk prejudicing pending criminal proceedings and our law of contempt of court buttresses that expectation. It does not, however, do so in an effective manner. The Contempt of Court Act 1981 makes it an offence of strict liability to publish matter which "creates a substantial risk that the course of justice in the proceedings in question will be seriously impeded or prejudiced". This twofold requirement of substantial risk of serious prejudice is not easily satisfied. It will not apply to individual publications which are unlikely to come to the notice of potential jurors. This raises the almost insoluble problem of the incremental effect of publications, no single one of which can be said to create a substantial risk of serious prejudice but which, when taken together, certainly do so.

Prejudicial media coverage has led to a new phenomenon on the English judicial scene. The application for a stay of criminal proceedings on the ground that the trial will constitute an abuse of process. The basis of such applications is that the adverse publicity has been so intense that members of any jury selected are likely to be infected by prejudice against the defendant.

Such applications have been lent credibility by a decision of our Court of Appeal which gave as one reason for allowing an appeal against conviction the possible effect on the members of the jury of unbridled, and inacrurate, media coverage. I believe that in at least four recent cases stay applications on the ground of prejudicial media coverage have been successful.

In a trial over which I presided recently defence counsel applied for a stay on the ground of adverse publicity. In support of this application they adduced extensive Gallup poll evidence of the effect of this publicity on the attitude to the defendants of those questioned. The prosecution did not challenge the contention that this indicated a real risk that in a jury selected at random there would be some jurors prejudiced against the defendants.

In those circumstances I adopted a course that was without precedent. I settled, with the help of counsel, a questionnaire designed to identify those potential jurors who might be prejudiced as the result of the media coverage. Each member of the panel from which the jury 
would be selected was required to complete this questionnaire. The potential jurors were kept out of court when the selection ballot took place. As each juror was selected I considered his or her questionnaire with counsel and then questioned the juror to explore any possibility of prejudice suggested by the questionnaire. In the light of the answers I received, and with the express or tacit approval of counsel, I excused from serving close on $50 \%$ of those selected.

I adopted this course with reluctance. It seemed to me, and it still seems, that I might be setting a dangerous precedent and inserting into our system the thin end of a wedge that might result in a practice of American style jury selection. I know of one case already where my example has been followed - but it certainly seems to me a lesser evil than staying proceedings on the ground that there can be no fair trial.

I should mention that I was shown a recent decision of your Court of Appeal - $R v$ Sanders. ${ }^{7}$ There counsel for a defendant suggested that a questionnaire similar to mine should have been used. Cooke $\mathrm{P}$, after listing the proposed questions, said:

It is hardly necessary to do more than to reproduce that list to bring out the intrusive, inconclusive, and time-consuming inquiries which an inquisition of that kind would introduce into jury balloting. New Zealand law should not go down that road.

So there is perhaps not a great danger of my having set a precedent that will be followed in New Zealand.

I have encroached on a topic that merits a lecture of its own - the role and influence of the media in relation to the administration of justice.

\section{Majority Verdicts}

In England if the jury has not returned a verdict within two hours, the judge can accept a majority verdict - ie a verdict of at least 10 out of $12-10$ out of 11 if the jury is down to that number, or 9 out of 10 if the jury is down to 10 . This provision is, I believe, a very useful one. The two hour limit is a minimum and, in general, the judge will not give a majority direction until the foreman of the jury indicates that they are deadlocked. A majority verdict is a common experience and one that should occasion no surprise. If you select twelve jurors at random there must be a fair change of selecting one or two who are too stupid or pig-headed to see what is obvious - or indeed so biased or malicious as to act with deliberate perversity.

I do not know how often you experience hung juries in New Zealand, but I have no doubt that you will have less if you introduce majority verdicts. Of course this reduces the protection that the system provides against the conviction of an innocent defendant, but I

7 (1995) 13 CRNZ 222, 228-229. 
believe that if you retain a requirement for a majority of over $80 \%$, you cater for the rogue juror without significantly increasing the risk of an unjust conviction.

That concludes a brief summary of some of the particular areas of practice in relation to jury trials that are receiving consideration. I now wish to turn to aspects of jury trial in England and Wales that have caused me concern. I shall be interested to learn whether these concerns strike any chord with those who practise here.

\section{EVIDENCE}

Under the English adversarial system it is for the parties to decide the evidence that is to be placed before the jury. This contrasts with the inquisitorial system that prevails in the civil law countries where the judiciary supervises the enquiry into the facts and the marshalling of the evidence that will be presented at the trial.

In France in the case of serious crimes an examining Magistrat or Juge d'Instruction oversees the gathering of evidence and interviews witnesses and the defendant in order to decide whether there is a case to answer. If there is, the dossier of the evidence obtained by the Juge d'Instruction is passed to the judge who presides over the trial, and the judge uses it as a basis for questioning the defendant and witnesses. In the Cour d'Assises where the serious crimes are tried the presiding judge sits with two legal assessors and a lay jury of nine. At the end of the trial they all retire together and together determine both verdict and, if the verdict is guilty, as it usually is, sentence. A guilty verdict requires a majority of at least 8 to 4 for conviction, so the lay jurors are always in a position to outvote the professionals. The professionals will, however, be able to assist in the evaluation of the evidence. This contrasts with the English system under which, once they retire, the jury are left alone to their deliberations, although they can of course send a note if they need assistance on a specific point. This contrast of procedures renders less shocking to common law eyes, but only slightly less shocking, the fact that under the French system there are virtually no rules of evidence that restrict the admissibility of what can be introduced at the trial. Let me describe the start of a rape case that I saw in Paris - which was in no way untypical.

The President started by examining the defendant as to his two previous convictions for rape:

Is it correct that you have committed rape on two previous occasions?

No it is not.

I see - you have already had the misfortune to be twice wrongly convicted? I have received a letter from your mother. Let me read it to you. "I am not surprised that Jean-Pierre has been guilty of rape. When we were in the Pacific he was always forcing himself on the local girls" is that correct? 
No - I prefer French girls.

Then two psychiatrists were called who gave evidence of the defendant's propensity to commit rape - in terms that took his guilt for granted.

No doubt the judges who retire with the jury can instruct them of the limitations on the probative weight of matters such as these, but one cannot but think that they must still have a potent effect in instilling in the French jurors the "conviction intime" or "inner certainty" of guilt that is in France the test that is the counterpart of our requirement for certainty beyond all reasonable doubt.

Under our system the evidence that can be placed before the jury is restricted by a series of complex rules, the appreciation of which is the task of the judge. The judge has to deal with issues of admissibility either before the trial begins or as it progresses - ruling on issues after hearing argument in the absence of the jury.

The role of the judge as a filter of evidence serves two overlapping functions:

1) It enables the judge to review the manner in which the evidence has been obtained, excluding where appropriate evidence which has been obtained in circumstances of impropriety.

2) It enables the judge to withhold from the jury evidence deemed to be unreliable.

The type of evidence most commonly challenged under these heads is evidence of confessions. Under the common law the earlier decisions did not make it clear whether the power of a judge to exclude confessions improperly obtained derived from the fact that such confessions were unreliable, or reflected a more fundamental policy. By 1980 it had become apparent that the latter was the case. In Wong Kam-ming $v$ The Queen ${ }^{8}$ Lord Hailsham said:

any civilised system of criminal jurisprudence must accord to the judiciary some means of excluding confessions or admissions obtained by improper methods. This is not only because of the potential unreliability of such statements, but also, and perhaps mainly, because in a civilised society it is vital that persons in custody or charged with offences should not be subjected to ill treatment or improper pressure in order to extract confessions. It is therefore of very great importance that the courts should continue to insist that before extra-judicial statements can be admitted in evidence the prosecution must be made to prove beyond reasonable doubt that the statement was not obtained in a manner which should be reprobated and was therefore in the truest sense voluntary.

$8 \quad[1980]$ AC 247, 261. 
In $R v$ Sang $^{9}$ the question arose of whether this general principle extended to permit a judge to exclude evidence of criminal behaviour induced by an agent provocateur. The House of Lords held that it did not. Lord Diplock put the matter thus:

Outside this limited field in which for historical reasons the function of the trial judge extended to imposing sanctions for improper conduct on the part of the prosecution before the commencement of the proceedings in inducing the accused by threats, favour or trickery to provide evidence against himself, your Lordships should, I think, make it clear that the function of the judge at a criminal trial as respects the admission of evidence is to ensure that the accused has a fair trial according to law. It is no part of a judge's function to exercise disciplinary powers over the police or prosecution as respects the way in which evidence to be used at the trial is obtained by them. If it was obtained illegally there will be a remedy in civil law; if it was obtained legally but in breach of the rules of conduct for the police, this is a matter for the appropriate disciplinary authority to deal with. What the judge at the trial is concerned with is not how the evidence sought to be adduced by the prosecution has been obtained, but with how it is used by the prosecution at the trial.

A fair trial according to law involves, in the case of a trial upon indictment, that it should take place before a judge and a jury; that the case against the accused should be provided to the satisfaction of the jury beyond all reasonable doubt upon evidence that is admissible in law; and as a corollary to this, that there should be excluded from the jury information about the accused which is likely to have a influence on their minds prejudicial to the accused which is out of proportion to the true probative value of admissible evidence conveying that information. If these conditions are fulfilled and the jury receive correct instructions from the judge as to the law applicable to the case, the requirement that the accused should have a fair trial according to law is, in my view, satisfied; for the fairness of a trial according to law is not all one-sided; it requires that those who are undoubtedly guilty should be convicted as well as those about whose guilt there is any reasonable doubt should be acquitted. However much the judge may dislike the way in which a particular piece of evidence was obtained before proceedings were commenced, if it is admissible evidence probative of the accused's guilt it is no part of his judicial function to exclude it for this reason. If your Lordships so hold you will be reverting to the law as it was laid down by Lord Moulton in Rex v Christie [1914] AC 545, Lord du Parcq in Noor Mohamed $v$ The King [1949] AC 182 and Viscount Simon in Harris $v$ Director of Public Prosecutions [1952] AC 694 before the growth of what I believe to have been a misunderstanding of Lord Goddard's dictum in Kuruma $v$ The Queen [1955] AC 197.

It is open to question whether this passage of the speech of Lord Diplock has survived the Police and Criminal Evidence Act 1984. Section 78 of that Act provides:

9 [1980] AC 402, 436-437. 
In any proceedings the Court may refuse to allow evidence on which the Prosecution proposes to rely to be given if it appears to the Court that, having regard to all the circumstances, including the circumstances in which the evidence was obtained, the admission of the evidence would have such an adverse effect on the fairness of the proceedings that the Court ought not to admit it.

This section has most frequently been used to exclude evidence obtained in a breach of the statutory code that governs Police conduct, but the cases fully establish the principle that the manner in which evidence is obtained can, of itself and without more, taint the subsequent legal proceedings so as to render them unfair.

How about the principle, referred to by Lord Diplock, that: ${ }^{10}$

there should be excluded from the jury information about the accused which is likely to have an influence on their minds prejudicial to the accused which is out of proportion to the true probative value of admissible evidence conveying that information.

This is the principle which has excluded from the jury the fact that a defendant has a criminal record; this is the principle that has resulted in severance of charges that a father has sexually molested a number of his children on the ground that the evidence of one child would be unfairly prejudicial to the defendant when defending himself against the charge in respect of another.

It is a principle whose application has reflected an ambivalence which runs right through our criminal justice system and which, I believe, has tended to flaw it. While we pay lip service to the concept that the jury is the ideal fact-finding tribunal - a tribunal that can be relied upon to apply a robust common sense to the evidence - in fact we do not trust the jury to do that.

The English juror is not given evidence that indicates a propensity on the part of the defendant to commit the type of offence with which he is charged. The French juror is given this evidence. Such evidence is relevant and probative. Why do we assume that the jury will give it more weight than it deserves? Perhaps because we feel that we should risk doing so ourselves - that human nature carries with it the risk that such evidence will carry greater prejudice than its probative weight merits.

In England the "similar facts" rule, which excluded evidence of the commission of other offences of the type charged unless accompanied by features of "striking similarity" has been relaxed by the House of Lords in DPP $v P{ }^{11}$ The sole speech of the Lord Chancellor has

10 Above n 9, 437.

11 [1991] 2 AC 447. 
been criticised by some academics on the ground that it does not propound a test of admissibility that is rigidly defined. For my part that is its virtue.

No one who had seen members of a jury break down in tears on learning that the man they have just acquitted of a sexual offence was to stand trial for a similar offence, severed on the ground that there were no striking similar features, could have felt that the state of our law was satisfactory.

I have contrasted our restraints on admissibility with an extreme example of the unrestricted approach to the evidence in France, and I do not suggest that the latter is manifestly more attractive. What I do believe is that rules that prevent relevant material being placed before the tribunal of fact must be kept under constant scrutiny to ensure that they are justified. The rule against hearsay evidence - unknown in France - is a rule which can result in the suppression of cogent evidence - particularly where the evidence is in the form of contemporary documents. This fact is reflected by the many exceptions that have been created to the hearsay rule.

In England the Civil Evidence Acts of 1968 and 1972 significantly relaxed the hearsay rule in civil proceedings. The rule precluded the admission of much documentary evidence in the criminal jurisdiction, until 1988, when s 24 of the Criminal Justice Act 1988 permitted the introduction in a criminal trial of a document provided that:

it was created or received by a person in the course of a trade, business, profession or other occupation, or as a holder of a paid or unpaid office and

(2) the information contained in the document was supplied by a person (whether or not the maker of the document and whether supplied directly or indirectly) had, or may reasonably be supposed to have had, personal knowledge of the matters dealt with.

These provisions have made drastic inroads into the hearsay rule - a fact that was not at first appreciated. Indeed they make admissible in a criminal trial documents which could not be adduced in civil proceedings under the Civil Evidence Acts.

Nonetheless I believe that the hearsay rule demands critical reappraisal in both the civil and criminal fields and this it is currently receiving from our Law Commission.

\section{A The Summing-up and the Appeal Process}

The interrelationship of the summing up and the appeal process is where I feel that the jury system has run into trouble in our jurisdiction. In all common law jurisdictions that have retained the jury system the judge directs them as to the law. The approach as to summing up the facts differs, however. In America I understand that it is not the practice for the judge to sum up the facts at all. In Scotland the judge gives a very brief outline of the facts. In England and Wales it is the practice to give a fairly detailed précis of the relevant 
evidence. When I was receiving instruction as a recorder I was told that a good rule of thumb was that each day's evidence should be condensed into about half an hour of summing up. This still seems to be the case and it is not uncommon for a lengthy fraud trial to result in a summing up that lasts over a week. Not only does the judge summarise the evidence, but where it is considered appropriate, directs the jury of the approach that they should adopt in their consideration of specific parts of the evidence.

The statutory provisions governing criminal appeals in England and Wales have just been changed, but both before and after the change the Court of Appeal has had the power and the duty to allow an appeal against any conviction that it has considered to be unsafe.

In $R v$ Cooper $^{12}$ Widgery LJ said this:

The Court must in the end ask itself a subjective question, whether we are content to let the matter stand as it is, or whether there is not some lurking doubt in our minds which makes us wonder whether an injustice has been done. This is a reason which may not be based strictly on the evidence as such; it is a reaction which can be produced by the general feel of the case as the Court experiences it.

Since that judgment, the Court of Appeal have frequently been urged to feel that there is a lurking doubt, but has been slow to adopt this sensation as a ground for allowing appeals. The court has, however, been much more ready to allow an appeal on the basis that the summing up has been in some respect deficient. Once a deficiency has been identified, subsequent decisions tend to build on it and extend it, so that there develops, incrementally, a judge-made code of what the trial judge should or should not say to the jury. Failure to comply with this code is treated as an irregularity which vitiates the conviction.

The Judicial Studies Board publishes specimen directions which accord with the code and which the conscientious trial judge inserts verbatim, as appropriate, into his summing up. The end result is that the trial judge is required, if the verdict is not to be vitiated, to give directions to the jury on what are essential matters of common sense that those on the jury ought to be able to work out for themselves. Sometimes the judge is required go through an incantation of a direction which is contrary to common sense. Let me give one or two examples.

\section{B Corroboration}

Until recently English law included a considerable number of different situations in which either corroboration of a witness was necessary or a warning of the danger of convicting without corroboration was mandatory. The most notable or notorious were cases of sexual offences where this warning had to be given in relation to the complainant's evidence, whatever were the circumstances. In some instances the requirement was

12 [1969] 1 QB 267. 
statutory, but it had its roots in judgments of the Court of Appeal dealing with directions that had to be given about the approach that the jury should adopt to assessing factual evidence. The law in relation to corroboration developed greater and greater complexity. Ultimately it was appreciated that the inflexible requirements of this judge-made law had resulted in cases where juries received directions which were an affront to common sense and the requirements for corroboration had to be abolished by statute.

\section{The Right of Silence}

Judges used to comment robustly on the fact that a defendant had not chosen to testify, but incrementally a required direction developed to the stage where it was mandatory to direct the jury that no adverse inference could be drawn from the fact that a defendant had not gone into the witness box. This direction was manifestly in conflict with common sense - to the extent that some Judges made a practice of emphasising it heavily in the hope that the jury would focus on the contrary logical implication to be drawn from the defendant's silence. The legislation has now stepped in to provide by s 35 of the Criminal Justice and Public Order Act 1994 that juries can, in defined circumstances, be told that they "may draw such inferences as appear proper from the failure of the accused to give evidence".

The section of the Act that makes provision for this power is 34 lines long. The Judicial Studies board has produced a specimen direction which is 21 lines long - and all of this deals with the circumstances in which the jury may be told they are permitted to draw inferences which are a matter of common sense. This piece of legislation provides an extensive foundation upon which I fear there will be constructed another huge edifice of jurisprudence as to what judges can and cannot properly say when a defendant does not go into the witness box.

\section{The Defendant's Character}

If a defendant has no previous convictions, evidence that he or she is a person of good character will be placed before the jury. If he has previous convictions, the jury will not normally learn of this, though there may be circumstances which result in evidence of the defendant's bad character being placed before the jury.

In 1918 in Broadhurst ${ }^{13}$ the Court of Appeal upheld a direction that the jury "should only have regard to the Defendant's good character if they were in doubt as to his guilt". How different things are today. In $R v V y e^{14}$ the Court of Appeal had cited to it no less than 32 cases dealing with directions as to a defendant's character. These led the court to hold that, where a defendant has a good character, it is mandatory for the judge to explain to the jury that good character is relevant for two reasons. First that it is relevant when 13 [1918] Cr App R 125.

14 [1993] 1 WLR 471. 
considering the likelihood that the defendant has committed the offence charged and secondly because it enhances the credibility of evidence the defendant has given or of exculpatory statements that the defendant has made to the police. This raises a problem if a defendant with good character is charged with one whose bad character has gone in evidence, for the judge is required to tell the jury that bad character does not make it more likely that the defendant has committed the offence charged. Failure to give these directions will almost automatically result in the quashing of a conviction. The House of Lords has approved this decision.

The length to which the requirement to give a good character direction has been taken is exemplified by the recent case of Durbin. ${ }^{15}$ There the defendant who was charged with importing cannabis admitted that he had told lies and averred that he had been engaged in smuggling goods across the frontiers of European countries. No good character direction was given. The Court of Appeal held that a good character direction should have been given, modified to have regard to the blemishes I have just referred to. The conviction was quashed and a retrial ordered.

I find the requirement to give directions such as these offensive. I do not believe that it should even be mandatory for the court to give juries directions about matters which are simply a matter of common sense. Why should we not trust juries to draw such conclusions as logically follow from the fact that a defendant is of good character? A fortiori, I do not believe that the court should ever be required to give juries directions which are in conflict with common sense, such as saying that a criminal record does not indicate a propensity to commit crimes.

If juries cannot be trusted to apply common sense to the factual evidence, but have to be given the assistance of the greater wisdom and experience of judges, then it seems to me the justification for having juries rather than judges as the tribunals of fact is largely destroyed.

There are other ways in which a contemporary lack of trust in juries is manifested.

In the old days juries were locked up without food or drink until they produced their verdicts. It was not considered that this rendered the verdicts suspect.

As late as 1909, in Hartleigh, ${ }^{16}$ when an appellant complained that the jury only reached agreement after the judge had told them that they would be locked up for two hours, the Court of Appeal remarked that the procedure was regular and there was no reason for interfering.

15 [1995] 2 Cr App R 84.

16 [1908] 1 Cr App R 17. 
Compare this to Wharton. ${ }^{17}$ There at $6.10 \mathrm{pm}$ the jury sent a note saying that they had reached a verdict 9-3. The judge, with the concurrence of counsel, sent a message asking them to continue their deliberations. At $6.25 \mathrm{pm}$ they returned a guilty verdict 10-2. The Court of Appeal quashed the conviction, apparently on the ground that the jury might have been pressurised to reach their verdict, with the consequence that it was unsafe.

If we are to continue to entrust criminal trials to juries, then I believe we ought to trust them to use ordinary common sense and to show a reasonable robustness in resisting pressures and prejudices so as to arrive at verdicts in accordance with their oaths. The importance that is attached to the transitory phrase in the summing up is unrealistic and unbalanced, but it is deeply entrenched in our system.

I have been expressing concerns about some of the developments of jury trials in my jurisdiction. In the United States there are other causes for concern. But notwithstanding these I do not believe the case is made out for replacing the jury with a judicial tribunal in the case of the ordinary criminal trial. Where, as so often, the trial turns on an evaluation of human nature - where the issue is whether the complainant consented; whether the shopper intended to steal; whether the wound in the pub fight was inflicted with intention to do serious harm - then I believe that the jury is a more satisfactory tribunal than the judge, though neither tribunal can be infallible. When the political advantages of jury trial are added to the scale, I think that it tilts decisively in favour of the status quo. That, however, is subject to what I have to say about the complex and lengthy trial.

\section{SHOULD JURIES TRY COMPLEX CASES OF SERIOUS FRAUD?}

I am frequently asked the question - how can juries possibly be expected to understand complex serious fraud cases? Let me say straightaway that so far as concerns the two such cases that I have tried, I have no reason to think that the juries were unable to understand the issues or to address them logically and nothing that I say should be taken as impugning the verdicts in those cases. I have, however, for the reasons that I am about to give, formed the firm view that jury trial is not a satisfactory way of dealing with a long and complex case.

\section{A The Selection of the Jury}

Whatever the theory may be, the practice is that any prospective juror who is unwilling to serve on a trial that is estimated to run for months is likely to be able to get excused from doing so. In a trial of that length one or more jurors who are unwilling and resentful can spell disaster. Most who are unwilling to serve are likely to be unwilling to do so for good reason. Children to care for, holidays booked and paid for, businesses to run, employment that will be jeopardised by a lengthy period of absence. Those without such conflicting 17 [1990] Crim LR 877. 
commitments will not represent a fair cross-section of the community and are not likely to include experience of the business environment that will form the background of the trial. For those who are selected the duration of the trial and the demands made on them are likely to be stressful. A good jury will gel together and form a team. Personality clashes in a jury can, however, be fatal to calm and reasoned deliberation. I have had the good fortune of experiencing juries who got on well and applied themselves conscientiously to their duties, but I have spoken to colleagues who have experienced juries which have manifestly been riven by dissent and mutual dislike. In one fraud case recently, which had lasted for months, the judge was driven to discharge the jury because it was clear that they had lost all grip on the case.

In summary I believe that the effect that the length of a trial has both on jury selection and on the jurors who are selected can impair the ability of the jury to make a balanced assessment of the evidence.

\section{B The Complexity of the Subject Matter}

Those who attack jury trial of serious fraud argue that juries cannot be expected to understand the subject matter of the trial Those who support the jury contend that at the heart of every fraud case there is one simple issue - was the defendant dishonest? Juries, they argue, are best able to answer that question. As to the complexity, competent prosecuting counsel and a competent judge can and should reduce the bulk of the case to a dimension that the jury can accommodate.

In reviewing Kellard, ${ }^{18}$ a trial which had occupied 252 working days, the Court of Appeal remarked:

$\ldots$ it is the duty of prosecution counsel to review the evidence in a long case and decide how much of it, even though relevant, can be withheld in the interests of time and clarity.

Furthermore, when the Judge is minded to sever the indictment, it is not appropriate for prosecution counsel to frustrate the Judge's purpose by calling the evidence supporting the severed count or counts, on the basis that it is relevant to those remaining.

I believe that it will normally be possible for a competent judge, with the co-operation of competent and conscientious counsel for both prosecution and defence, by a process of severing counts and ring-fencing evidence, to reduce the case to a dimension that the jury can comprehend. But this presupposes a high degree of competence on the part of those concerned, perhaps higher than one can reasonably expect to be widely available, and if a defence counsel sets out to spoil rather than to co-operate (not happily a situation that I have experienced) I believe such a course is likely to render a trial unmanageable. But this process only renders the trial manageable by removing from the jury a large (sometimes even 
the major) part of the evidence that is relevant to the central issue - the honesty of the defendant. Often the evidence that is ring-fenced from the jury is cogent. I believe that a trial process that requires one to remove from the tribunal a large part of the relevant evidence, because it would otherwise overwhelm the tribunal, is seriously flawed and, so far as I am concerned, this is the primary reason why I consider that complex fraud cases should not be trial by juries.

\section{The Trial Process}

The procedure of a jury trial is slow and laborious. Documents have to be read to the jury and witnesses often appear to be no more than a backcloth for this process. Frequent, and sometimes, lengthy interruptions take place while points of admissibility are canvassed. Furthermore, where it appears to defence counsel that there is no obvious answer to the prosecution's case, or even sometimes where there does appear to be an answer, there will be a natural temptation to spend time pursuing matters of only fringe relevance that have, or are perceived as having, a potential for obfuscating the true issues. I suspect that juries often see through such tactics, but there is always the hope, if not the expectation, that they may not. If some of the mandatory directions of which I have spoken suggest that judges do not trust juries to use common sense, the same may be said of the tactics sometimes adopted by defence counsel. This I have found the most interesting feature of a recent study by Jackson and Doran which has compared the Diplock trial with the conventional jury trial. $^{19}$

I should explain that "Diplock Courts" are courts in Northern Ireland where serious offences, which may have terrorist implications, are tried by judge alone, but where otherwise the procedure followed is the same as in the case of jury trial.

The authors found that there was a greater tendency for defendants to plead guilty in the case of the Diplock trial than in the case of jury trial. As one defence counsel commented: ${ }^{20}$

with the jury things can always go wrong.

or as another put it: ${ }^{21}$

in a jury case you tend to put them to proof because a wheel can always fall off somewhere along the way.

It is clear from Jackson and Doran's researches that counsel adopt a very different attitude when trial is by judge alone to that which they adopt before a jury. They found that

19 Jackson and Doran Judge Without Jury (Clarendon Press, Oxford, 1995).

20 Above n 18, 170.

21 Above n 18, 201. 
the absence of the jury restrained the conduct of counsel and increased the judge's discretion to control the trial as he wished. 22

There was a greater tendency in Diplock trials for facts to be agreed and issues to be pared down. ${ }^{23}$ As one defence counsel put it: ${ }^{24}$

All the theatricals and the advocacy tend to get side-lined. It's "Let's get to the main issue and get it dealt with", be it a legal issue or a factual issue.

In the view of the prosecution, Diplock proceedings were more akin to a problem solving exercise than an adversarial contest. ${ }^{25}$ This echoed comments from judges to the effect that in a Diplock trial the judge is able to have a much freer discussion with counsel about the effect of the evidence.

I believe that jury trial places severe restrictions on the kind of case management that is particularly desirable when faced by a huge amount of evidence. If such cases were tried by judge alone, or judge plus assessors, I have no doubt that the attitude of defence counsel would be very different. It would be or become apparent to counsel which issues the judge considered significant and which peripheral, and counsel would focus on the former. There would be scope for procuring agreement of facts and narrowing of the issues as the trial progressed.

The Diplock Courts follow precisely the same procedure as that adopted in jury trials, but I consider that if cases were removed from juries on the grounds of their length or complexity, there should be a fundamental review of the procedure to be adopted in such cases, designed to ensure that the true issues were identified at the outset. We have already taken some steps in that direction with the preparatory hearing that normally precedes a serious fraud trial.

There are many other ways in which trial before a judicial tribunal would be more streamlined and efficient, not least that the tribunal could read the relevant documents rather than having every word read aloud in court.

I was interested to learn that in New Zealand the right exists for a defendant charged with serious fraud to elect for trial by judge rather than jury, and that increasing numbers of defendants are so electing. This suggests that the reasoning of defence lawyers described by Jackson and Doran may not be as prevalent in this country.

22 Above $\mathrm{n} 18,163$.

23 Above n 18, 200.

24 Above n 18, 195.

25 Above n 18, 208. 


\section{Reasoned Judgment}

The complex serious fraud trial usually involves issues which are susceptible to reasoned analysis, based in large measure on contemporary documentary evidence. In the case of jury trial it is impossible to know by what process the verdict is reached. If the jury have misappreciated the facts or followed an erroneous chain of logic this will never be apparent. A judicial tribunal would, however, be required to justify its verdict with a reasoned judgment. Thus verdicts would be more readily susceptible to re-appraisal on appeal. I consider that this is an important argument in favour of trial by judge alone, or judge and assessors. I have put to many lawyers the question - "If you were charged with fraud of which you were innocent, would you rather have a jury or a reasoned judgment from a competent judge". All but one preferred the latter.

\section{E The Alternative to the Jury}

What alternative would I propose to the jury in cases of complex fraud: single judge, or judge plus two assessors? Either would, I believe, be more satisfactory than the jury, but neither would be ideal. A complex fraud trial is too taxing to be tried by a single judge. It is essential to have someone with whom to discuss the case, or one is at risk of losing one's sense of proportion. Assessors can be of great assistance in they are of high calibre and objectivity. If they are not, then there is a danger of their providing, unknown to counsel, an input that is unreliable. Ideally I would prefer a three judge court - though I recognise the strain this would place on limited judicial resources.

What should be the criteria that would result in the substitution of the judicial tribunal, whatever its precise make up, for the jury? While I have spoken of this substitution in the context of complex fraud trials, there are other complex or lengthy trials where similar considerations apply. I would favour giving the court power to order trial by the judicial tribunal in any case where, by reason of the likely length or complexity of the trial or for any other reason the court considered it was unsuitable for trial by jury, with a right of appeal against such order to the Court of Appeal. 
